\title{
A Espacialização do Latifúndio, os Impasses à Política de Assentamentos e a Eficiência Camponesa em Ivinhema - MS
}

\author{
The Spatialization of Large Property, Impasses to Settlement Policy and Peasant \\ Efficiency in Ivinhema - MS
} La Espacialización del Latifundio, los Impasses a la Política de Asentamientos y la
Eficiencia Campesina en Ivinhema-MS

\begin{abstract}
RESUMO: O presente trabalho pretende discutir a espacialização do latifúndio e os desdobramentos socioambientais e políticos desse processo bem como as tensões de classe entre o latifúndio e o campesinato enquanto portadores de objetivos conflitantes no campo. Para tanto, parte-se da teoria da renda da terra e da função social da terra para a compreensão da constituição do latifúndio produtivo e suas características, o que supõe reposicionar o uso do termo agronegócio. Dessa forma, o objetivo do trabalho é evidenciar como a concentração fundiária provoca efeitos devastadores para a sociedade, ao mesmo tempo em que a unidade de produção camponesa se apresenta como portadora da capacidade de cumprimento da função social da terra. Os estudos que o comprovam estão baseados no recorte espacial do município de Ivinhema, localizado no sudoeste de Mato Grosso do Sul. A metodologia utilizada consistiu em levantamento bibliográfico em livros, periódicos e jornais sobre os temas, levantamento de dados nos censos agropecuários e da produção agrícola municipal do IBGE, informações sobre a estrutura agrária de Ivinhema junto ao INCRA e obtenção de informações por meio de entrevistas realizadas com servidores públicos, proprietários capitalistas e camponeses no município. Após a análise dos dados à luz da base teórica utilizada, constatou-se a prevalência do caráter rentista da propriedade privada capitalista da terra, aqui caracterizada como latifúndio improdutivo e latifúndio produtivo, em vista das distinções entre ambos, aos quais se confrontou a agricultura camponesa, qualitativamente oposta a ambos em vista do uso produtivo da terra.
\end{abstract}

PALAVRAS-CHAVE: Latifúndio improdutivo; Latifúndio produtivo; Campesinato; Função social da terra.

\begin{abstract}
The present work intends to discuss the spatialization of the latifundio and the socioenvironmental and political unfolding of this process as well as the class tensions between the latifundio and the peasantry as bearers of conflicting objectives in the field. In order to do so, it is based on the theory of land rent and the social function of the land for the understanding of the constitution of productive latifundia and its characteristics, which presupposes repositioning the use of the term agribusiness. Thus, the objective of the study is to show how land concentration has a devastating effect on society, at the same time that the peasant production unit presents itself as having the capacity to fulfill the social function of the land. The studies that prove this are based on the
\end{abstract}


spatial clipping of the municipality of Ivinhema, located in the southwest of Mato Grosso do Sul. The methodology used consisted of a bibliographical survey in books, periodicals and newspapers on the subjects, data collection in agricultural censuses and production municipal IBGE, information on Ivinhema's agrarian structure with INCRA, and obtaining information through interviews with public servants, capitalist owners and peasants in the municipality. After analyzing the data in the light of the theoretical basis used, the prevalence of the rentier character of the private capitalist property of the land, here characterized as unproductive latifúndio and productive latifundio, in view of the distinctions between both, to which agriculture was confronted peasant, qualitatively opposed to both in view of the productive use of land.

KEYWORDS: Unproductive latifundio; Productive latifundio; Peasantry function of the land.

RESUMEN: El presente trabajo pretende discutir la espacialización del latifundio y los desdoblamientos socioambientales y políticos de ese proceso así como las tensiones de clase entre el latifundio y el campesinado como portadores de objetivos conflictivos en el campo. Para ello, se parte de la teoría de la renta de la tierra y de la función social de la tierra para la comprensión de la constitución del latifundio productivo y sus características, lo que supone reposicionar el uso del término agronegocio. De esta forma, el objetivo del trabajo es evidenciar cómo la concentración agraria provoca efectos devastadores para la sociedad, al mismo tiempo que la unidad de producción campesina se presenta como portadora de la capacidad de cumplimiento de la función social de la tierra. La metodología utilizada consistió en levantamiento bibliográfico en libros, periódicos y periódicos sobre los temas, levantamiento de datos en los censos agropecuarios y de la producción en el municipio de IBGE, informaciones sobre la estructura agraria de Ivinhema junto al INCRA y obtención de informaciones por medio de entrevistas realizadas con servidores públicos, propietarios capitalistas y campesinos en el municipio. Después del análisis de los datos a la luz de la base teórica utilizada, se constató la prevalencia del carácter rentista de la propiedad privada capitalista de la tierra, aquí caracterizada como latifundio improductivo y latifundio productivo, en vista de las distinciones entre ambos, a los cuales se confrontó la agricultura campesina, cualitativamente opuesta a ambos en vista del uso productivo de la tierra.

PALABRAS CLAVES: Latifundio improductivo; Latifundio productivo; Campesinado; Función social de la tierra.

Agradecimento:à CAPES pelo apoio financeiro para a realização dessa pesquisa.

Disponível em: http://www.bibliotecadigital.uel.br/document/?code=vtls000216178.

Recebido: outubro de 2017. Aceito: outubro de 2017. 